\title{
MENELISIK KERANCUAN ANTARA PENGAMALAN AJARAN AGAMA DAN BERBUDAYA SERTA IDEALITAS PENYELENGGARAAN DIKLAT MULTIKULTURAL
}

\author{
Ngamilah \\ Balai Diklat Keagamaan Semarang \\ Email: ngamilahbdk@gmail.com
}

\begin{abstract}
Abstrak
Agama dan budaya, keduanya memiliki kaitan yang sangat erat. Karena keeratannya itu , sehingga sulit untuk dibedakan antara pengamalan ajaran agama atau sekedar berbudaya. Akibatnya terjadinya kerancuan antara pengamalan ajaran agama dan berbudaya dalam kehidupan bermasyarakat, beragama dan berbangsa tidak dapat dihindarkan. Bertitik tolak dari realitas ini maka kajian ini dilakukan dengan tujuan untuk merumuskan pengertian agama dan budaya serta perbedaan antara keduanya, mendeskripsikan kerancuan yang terjadi di masyarakat terkait dengan pelaksanaan terhadap ajaran agama dan berbudaya, mendeskripsikan bagaimana memposisikan agama dan budaya dalam kehidupan bermasyarakat, beragama dan bernegara. serta mendiskripsikan penyelenggaraan Diklat Multikultural yang ideal. Sebagai penelitian kualitatif, maka observasi, wawancara dan dukumentasi menjadi andalan dalam pengumpulan data dalam penelitian ini. Pemikiran induktif, abstraktif ,logis dan sistematis merupakan ciri khas dalam penganalisaan data. Temuan pokok dalam penelitian ini adalah terjadinya kerancuan pemahaman terhadap agama dan budaya pada berbagai aspek kehidupan terkait dengan perilaku, etika berbusana dan aspek-aspek kehidupan lainnya yang asalnya budaya yang dimiliki oleh bangsa atau kelompok masyarakat tertentu.
\end{abstract}

Kata Kunci: kerancuan, ajaran agama, budaya

\begin{abstract}
Religion and culture have a very close relationship with one another. Because of its closeness, it is difficult to distinguish between the practice of religious teachings or just being cultured. As a result, the confusion between the practice of religious teachings and culture in community life, religion and nation cannot be avoided. Starting from this reality, this study was carried out with the aim of describing the understanding of religion and culture and the differences between the two implementation of religious and cultured teachings, describing how to position religion and culture in social, religious and state life. and describe the ideal implementation of Multicultural Education and Training. As a qualitative research, observations, interviews and documentation are the mainstays in collecting data in this study. Inductive, abstractive, logical and systematic thinking is a characteristic in ingrediets analyzing. The main finding in this study is the confusion of understanding of religion and culture in various aspects of life related to behavior, dress ethics and other aspects of life originating from cultures belonging to a particular nation or community group.
\end{abstract}

Keywords: confusion, religious teachings, culture 


\section{PENDAHULUAN}

K ehidupan manusia di dunia ini tidak dapat lepas dari pengaruh budaya yang menjadi kebiasaan hidupnya sehari-hari. Budaya akan menghasilkan cara manusia berpakaian, berbahasa dan berpikir sehingga pola hidup manusia di muka bumi ini akan berbeda-beda. Perbedaan budaya dipengaruhi oleh kemajuan jaman dan teknologi. Budaya manusia modem dengan teknologi komunikasi yang canggih sekarang tentulah berbeda dengan teknologi komunikasi dengan menggunakan burung merpati jaman dahulu. Perbedaan budaya ini merupakan hukum sunnatullah dan sebagian dari tanda-tanda kekuasaan Allah (QS al-rum [30]: 22) Relasi dan integrasi antar agama, etnis, gender, ras, dan budaya yang berbeda-beda dalam kehidupan berbangsa di negeri Indonesia ini tidak dapat dihindari. Demikian juga seiring dengan perjalanan waktu telah sering terjadi perlakuan yang tidak proporsional terhadap cultural tertentu, seperti perlakuan laki-laki terhadap perempuan dan lain-lain, bahkan gesekan atau konflik antar multicultural pun tidak dapat dihindari.

Pada sisi lain, karena sangat dekatnya antara ajaran agama dan budaya orang sulit membedakan. Karena memang antara ajaran agama dan budaya merupakan dual hal yang saling berhubungan sangat erat. Keduanya memiliki kesamaan dalam keberwujudannya yaitu sama-sama abstrak. Keduanya tidak bisa dilihat secara kasaf mata, akan tetapi dapat dinikmati dengan menggunakan panca indra, bahkan memberikan dampak positif dalam kehidupan umat manusia. Oleh karenya kehadiran keduanya sama-sama dibutuhkan manusia untuk menciptakan kehidupan yang lebih baik. Karena keduanya memberi batasan dan normanorma akan sesuatu yang diyakini kebenarannya oleh mereka yang menganutnya. Sehingga antara budaya dan ajaran agama tertentu sering terjadi kerancuan. Sulit dibedakan seorang dalam posisi tertentu sedang berbudaya atau sedang melaksanakan ajaran agama. Pada kedua hal ini akan menimbulkan konsekuensi yang berbeda.

Hal sebagaimana di atas terjadi di kalangan peserta Diklat Multikultural Balai Diklat Keagamaan Semarang tahun 2016. Mereka terdiri dari berbagai pemeluk agama, adat istiadat yang mereka bawa dari daerah asalnya. Sebelum mereka menerima materi dan wawasan sekitar multikultural, mereka memiliki pemahaman yang berbeda-beda terkait hubungan antara agama dan budaya. Mereka yang berasal dari agama Islam kebanyakan memiliki penilaian bahwa budaya-budaya yang berasal dari Arab menganggapnya sebagai ajaran Islam yang harus dilaksanakan oleh setiap Muslim. Namun ada juga di antara mereka yang menganggapnya bukan merupakan bagian dari ajaran Islam sehingga tidak ada kewajiban melaksanakannya. Sementara bagi peserta diklat yang non muslim menganggap hal itu merupakan bagian dari ajaran Islam dan merupakan bagian dari identitas muslim. Pemahaman yang berbeda-beda ini sudah barang tentu akan menimbulkan kerancuan di masyarakat dan akan menjadi persoalan tersendiri dalam 
kehidupan bermasyarakat, beragama dan berbangsa.

Berangkat dari persoalan-persoalan tersebut, adalah sangat menarik untuk diadakan kajian secara mendalam dari berbagai perspektif, untuk selanjutnya perlu adanya penjelasan pemisahan dan pembagian wilayah antara ajaran agama dan budaya serta memposisikan masingmasing dari keduanya secara tepat dan jelas. Artikel ini akan berusaha untuk mengungkap sekitar kerancuan tersebut dan memberikan pelurusan-pelurusan sesuai dengan kaidah-kaidah keterkaitan antara agama dan multikultural.

Pengamalan ajaran agama dalam kehidupan sehari-hari oleh para penganut agama, sering terjadi kerancuan antara pelaksanaan terhadap ajaran agama dan berbudaya. Persoalam tersebut ternyata juga terjadi di kalangan peserta diklat Multicultural yang juga merupakan bagian dari masyarakat. Kerancuan tersebut disebabkan oleh keterkaitan yang begitu erat antara agama dan budaya, sehingga antara keduanya sulit dibedakan apakah seseorang sedang melaksanakan ajaran yang dianutnya atau sekedar mengikuti budaya tertentu.

Untuk memberikan arah penelitian, maka masalah yang akan dicarikan jawabannya dalam penelitian ini adalah ; (1) Bagaimanakah rumusan pengertian agama dan budaya serta bagaimana membedakan antara agama dan budaya dan bagaimana relasi antara keduanya ? (2) Bagaimanakah kerancuan yang terjadi di masyarakat dalam pengamalan ajaran agama dan berbudaya dalam perspektif peserta Diklat Multikultural Angkatan I tahun 2016 di Balai Diklat Keagamaan Semarang?

(3) Bagaimanakah memposisikan agama dan budaya dalam kehidupan bermasyarakat, bergama dan bernegara? (4) Bagaimanakah Idealitas penyelenggaraan Diklat Multikultural ?

Sebagai tujuan penulisan ini adalah untuk mencari jawaban dari pertanyaanpertanyaan sebagaimana yang telah dirumuskan dalam perumusan masalah, yaitu; (1) mendeskripsikan rumusan pengertian agama dan budaya serta perbedaan antara keduanya, mendeskripsikan kerancuan yang terjadi di masyarakat terkait dengan pelaksanaan terhadap ajaran agama dan berbudaya, dan (3) mendeskripsikan bagaimana memposisikan agama dan budaya dalam kehidupan bermasyarakat, beragama dan bernegara. (4) mendiskripsikan penyelenggaraan Diklat Multikultural yang ideal.

Menurut

Koentjaraningrat (1987:180) budaya adalah keseluruhan sistem, gagasan, tindakan dan hasil kerja manusia dalam rangka kehidupan masyarakat yang dijadikan milik manusia dengan belajar. Jadi budaya diperoleh melalui belajar. Tindakan-tindakan yang _ dipelajari antara lain cara makan, minum, berpakaian, berbicara, bertani, bertukang, berrelasi dalam masyarakat adalah budaya. Tapi kebudayaan tidak saja terdapat dalam soal teknis tapi dalam gagasan yang terdapat dalam fikiran yang kemudian terwujud dalam seni, tatanan masyarakat, ethos kerja dan pandangan hidup. Yojachem Wach berkata tentang pengaruh agama terhadap budaya manusia yang immaterial bahwa mitologis hubungan kolektif tergantung pada pemikiran terhadap Tuhan.

Interaksi sosial dan keagamaan berpola kepada bagaimana mereka 
memikirkan Tuhan, menghayati dan membayangkan Tuhan (Wach, 1998:187). Lebih tegas dikatakan Geertz (1992:13), bahwa wahyu membentuk suatu struktur psikologis dalam benak manusia yang membentuk pandangan hidupnya, yang menjadi sarana individu atau kelompok individu yang mengarahkan tingkah laku mereka. Tetapi juga wahyu bukan saja menghasilkan budaya immaterial, tetapi juga dalam bentuk seni suara, ukiran, bangunan. Dapatlah disimpulkan bahwa budaya yang digerakkan agama timbu! dari proses interaksi manusia dengan kitab yang diyakini sebagai hasil daya kreatif pemeluk suatu agama tapi dikondisikan oleh konteks hidup pelakunya, yaitu faktor geografis, budaya dan beberapa kondisi yang objektif.

Faktor kondisi yang objektif menyebabkan terjadinya budaya agama yang berbeda-beda walaupun agama yang mengilhaminya adalah sama. Oleh karenanya, agama Kristen yang tumbuh di Sumatera Utara di Tanah Batak dengan yang di Maluku tidak begitu sama sebab masing-masing mempunyai cara-cara pengungkapannya yang berbeda-beda. Ada juga nuansa yang membedakan Islam yang tumbuh dalam masyarakat dimana pengaruh Hinduisme adalah kuat dengan yang tidak. Demikian juga ada perbedaan antara Hinduisme di Bali dengan Hinduisme di India, Buddhisme di Thailand dengan yang ada di Indonesia. Jadi budaya juga mempengaruhi agama. Budaya agama tersebut akan terus tumbuh dan berkembang sejalan dengan perkembangan kesejarahan dalam kondisi objektif dari kehidupan penganutnya (Andito,ed,1998:282).Tapi hal pokok bagi semua agama adalah bahwa agama berfungsi sebagai alat pengatur dan sekaligus membudayakannya dalam arti mengungkapkan apa yang ia percaya dalam bentuk-bentuk budaya yaitu dalam bentuk etis, seni bangunan, struktur masyarakat, adat istiadat dan lain-lain. Jadi ada pluraisme budaya berdasarkan kriteria agama. Hal ini terjadi karena manusia sebagai homoreligiosus merupakan insan yang berbudidaya dan dapat berkreasi dalam kebebasan menciptakan pelbagai objek realitas dan tata nilai baru berdasarkan inspirasi agama. Penelitian tentang agama dan budaya sudah banyak dilakukan, di antaranya dilakukan oleh Yudi Ruyadi dengan judul Model Pendidikan Karakter berbasis Kearifan Budaya Lokal (Penelitian terhadap Masyarakat Adat Kampung Benda Kerep Cirebon Provinsi Jawa Barat untuk Pengembangan Pendidikan Karakter di Sekolah).Penelitian ini menfokuskan pada pencarian jawaban sejauh mana budaya lokal memberikan dampak positif terhadap pendidikan karakter bagi siswa sekolah di kampung Benda Kerep Kabupaten Cirebon. Dalam penelitian ini Yudi menyimpulkan bahwa Pertama, masyarakat Kampung Benda Kerep memiliki pola pendidikan yang efektif dalam mewariskan nilai budaya dan tradisi kepada generasi berikutnya. Kedua, pendidikan karakter berbasis kearifan budaya lokal di sekolah telah memberikan dampak positif terhadap: siswa, sekolah, dan masyarakat. Ketiga, pendidikan karakter di sekolah akan efektif apabila: (a) nilai dasar karakter berasal dari budaya sekolah, keluarga, dan masyarakat, (b) program kurikuler dan ekstrakurikuler terintegrasi untuk mendukung pendidikan karakter, (c) kepala sekolah dan guru berperan sebagai 
teladan, pengganti orang tua di sekolah, pengayom, pengontrol dan pengendali terhadap prilaku budi pekerti siswa, dan (d) pelaksanaan pendidikan karakter berada pada situasi lingkungan budaya sekolah (Ruyadi, 2010: 40)

Tulisan lain tentang agama dan budaya adalah tulisan Vita Fiitria dengan judul: Interpretasi Budaya Clifford Geertz: Agama sebagai Sistem Budaya, yang dilatar-belakangi bahwa Pendekatan Geertz terhadap agama dapat dilihat dari dua sisi, sisi etnografi dan sisi teoritis. Untuk memahami posisi Geertz di antara teoritisi agama, perlu diperhatikan bahwa Geertz di didik di Universitas Harvard, bukan di Paris tempat Durkheim, atau Oxford tempat Pritchard. Maka ide Geertz tentang bu- daya dan agama berkembang dibawah dua pengaruh utama yaitu tradisi antropologi Amerika yang independen dan kuat, serta perspektif tentang ilmu sosial yang ia pelajari dari dosennya di Harvard, Tafcott Parsons. Geertz juga banyak terilhami dari para tokoh perintis antropogi lapangan sebelumnya seperti Eliade, Franz Boas, Alfred Louis Kroeber, Robert Lowie, serta Evan Pritchard. Vita Fitria yang tulisannya ini berkesimpulan bahwa Dalam pandangan Geertz, agama merupakan sebuah sistem holistik yang terkaitdengan lingkaran hermeneutis yang mencakup experience near concept yaitu makna yang dialami oleh penganutnya menuju experience distance concept yaitu. makna bagi orang luar dan sebaliknya. Faktor yang ada dalam diri manusia berupa motivasi dan ide mendorong seseorang untuk melakukan sesuatu yang luar biasa bagi dirinya. Sementara faktor eksternal berupa simbol-simbol yang merupakan ekspresi dari praktik-praktik tindakan individu secara bersama, sehingga agama merupakan simbol bentuk ekspresi dari tindakan-tindakan individu secara bersama. Terlepas dari berbagai kritik yang diarahkan kepada Geertz, kesuksesannya membangun "era interpretatif" dalam bidang antropologi dan menerapkan-nya dalam studi agama, telah menjadi rujukan para pemikir sesudahnya baik kalangan antropolog, agamawan, sosiolog maupun disiplin ilmu lain. Terobosan ini yang membuat dia dikenal sebagai tokoh antropologi modern (Fitria, 2012: 58).

Setelah melacak kajian-kajian yang sudah ada yang terkait dengan kajian sekitar Agama dan Budaya, penulis meyakini bahwa kajian yang penulis lakukan ini berbeda dengan kajian-kajian sebelumnya baik dari aspek fokus, materi, tujuan dan obyek kajian.

\section{METODE PENELITIAN}

Metode penelitian adalah cara- cara yang ditempuh dengan tujuan mendalami objek studi (Kuntjaraningrat, 1997: 8). Dalam penelitian yang penulis lakukan lebih menekankan pada jenis penelitian yang bersifat "kualitatif'. Metode Penelitian kualitatif dikembangkan melalui perkembangan ilmu pengetahuan yang berbasiskan pada teori Interpretatif.

Dalam penetitian kualitatif tidak diutamakan bahwa penelitian itu menghasilkan sesuatu yang benar atau salah, tetapi yang penting adalah hasil penelitian itu logis atau tidak logis. Sesuatu yang subyektif berarti tidak bebas nilai, interpretasi terhadap data dalam penelitian kualitatif bersifat kontekstual, kontesks budaya penulis maupun subyek yang diteliti juga dapat mempengaruhi hasil dari penelitianitu. Oleh karena itu 
dalam penelitian kualitatif, kerancuan antara agama dan budaya ini merupakan sesuatu yang dianggap unik, relatif dan tidak bisa digeneralisir seluruhnya.

\section{Obyek Penelitian}

Yang menjadi obyek atau sasaran penelitian ini adalah peserta Diklat Multikultural Angkatan I yang diselenggarakan oleh Balal Diklat Keagamaan Semarang tahun 2016 yang jumlahnya 30 orang. Dalam penelitian kualitatif pertimbangan pengambilan sampel bukan berdasarkan pada aspek keterwakilan populasi didalam sampel. Pertimbangannya lebih pada kemampuan sampel (informan) untuk memasok informasi selengkap mungkin kepada peneliti. (Patilima, 2010: 36). Dalam peneltian ini, dari 30 peserta diklat multikultural tersebut penulis mengambil enam peserta dengan mempertimbangkan kapasitas mereka terkait masalah penelitian yang sedang penulis teliti.Penentuan informan dilakukan setelah penulis mengamati dan mempelajari dokumen peserta diklat yang penulis peroleh dari panitia diklat. Dari enam informan inilah penulis melakukan kajian secara mendalam dalam rangka penggalian data dengan teknik yang penulis jelaskan.

Sumber data berdasarkan sumbernya, dibagi menjadi dua yaitu:

a. Data primer adalah data yang diperoleh langsung dari informasi atau objek yang akan diteliti. Dalam penelitian ini yang menjadi informan adalah peserta Diklat Multikultaral Angkatan 1 yang diselenggarakan oleh Balai Diklat Keagamaan Semarang tahun 2016 b. Data sekunder adalah data yang terlebih dahulu dikumpulkan atau dilaporkan oleh seseorang atau instansi diluar diri penulis sendiri.

\section{Teknik Pengumpulan Data}

Teknik pegumpulan data adalah suatu prosedur atau cara untuk mengetahui sesuatu yang mempunyai langkah-langkah sistematis. (Husein, 1996: 48) Pengumpulan data dalam penelitian ini dilgunakan teknik-teknik sebagai berikut :

\section{Observasi}

Observasi sebagai sebuah teknik pengumpulan data secara umum dapat dibagi kedalam dua jenis; pengamatan murni adalah pengamatan yang dilakukan oleh penulis dengan tidak melibatkan diri secara langsung dalam kegiatan yang berlangsung. Sedangkan yang kedua pengamatan terlibat yakni sebuah pengamatan sekaligus melibatkan dua hal pokok yaitu pengamatan dan wawancara.Kedua macam pengamatan tersebut digunakan dalam penelitian ini. Pengamatan terlibat dilakukan untuk melihat bagaimana cara informan atau subyek yang diteliti memilih tindakan tertentu dalam setiap kegiatan. Dengan menggunakan metode pengamatan terlibat ini diharapkan lahirnya ungkapanungkapan, pandangan-pandangan, emosi, dan harapan serta kehidupan sehari-hari dapat dipahami dan masuk di akal bagi penulis yang disesuaikan dengan logika yang berlaku dalam kebudayaan peseta diklat yang diteliti.

\section{Wawancara}

Metode wawancara dalam pelaksanaannya akan dilakukan dengan tiga tahapan pertama; merumuskan dan 
menyusun pedoman wawancara yang berisi garis-garis besar persoalan yang akan ditanyakan kepada informan. Hal ini dimaksudkan untuk memberikan arah pertanyaan dalam rangka memperoleh data yang betul-betul diperlukan dalam penelitian. Kedua; menentukan daftar personal calon informan yang memiliki kapasitas yang cukup terkait dengan persoalan penelitian. Ketiga,; mengatur kesepakatan daftar waktu pelaksanaan wawancara dengan informan.Dalam hal ini penulis dan informan yang merupakan peserta diklat memilih waktu di sela-sela kegiatan diklat. Keempat; pelaksanaan wawancara.(Kuntjaraningrat, 1990:130). Penggunaan metode wawancara ini dimaksudkan untuk mengumpulkan data primer dengan pertimbangan bahwa metode wawancara merupakan cara untuk mengumpulkan data secara langsung dari subyek penelitian dan mempunyai hubungan erat dengan obyek penelitian. Sistem yang digunakan dalam wawancara ini adalah bebas terpimpin. Dimaksudkan bebas karena peneliti tidak terpancang dengan daftar pertanyaan dan dikatakan terpimpin karena peneliti pegang rambu rambu yang berupa pedoman wawancara yang sudah peneliti siapkan sebelumnya.

\section{Dokumentasi}

Penggunaan metode dokumentasi ini dimaksudkan untuk mengumpulkan datadata primer yang berupa dokumendokumen penting yang diperoleh dari perpustakaan dan lembaga yang menjadi obyek penelitian.

\section{Teknik Analisa Data}

Data yang telah diperoleh melalui pengamatan, wawancara maupun dokumentasi akan dianalisis dengan teknik kualitatif dengan kerangka pikir induktif, abstraktif, logis dan sistematis. Adapun cara atau prosedur kerja analisis data secra rinci dapat diuraikan sebagai berikut:

c. Identifikasi dan katagorisasi (dipilah berdasarkan kelompoknya) hasil observasi dan wawancara sebagaimana masing-masing rumusan masalah yang diteliti. Pada langkah ini sekaligus dilaksanakan pengkodean data untuk masing-masing katagori. Koding dilakukan dengan sistematis sebagai berikut; e Digit pertama digunakan untuk menunjukkan nomor urut masalah sebagaimana urutan rumusan masalah.

$\checkmark$ Digit kedua pada penghubung.

$\checkmark$ Digit ketiga huruf o (observasi) atau w (wawancara) untuk menunjukkan teknik yang digunakan untuk mendapatkan data.

$\checkmark$ Digit keempat digunakan angka untuk menunjukkan nomor urut data untuk masing-masing masalah penelitian.

Contoh ;

|- $\mathrm{w} \mid$; data rumusan masalah pertama, data nomor urut | hasil wawancara

2-04; data rumusan masalah kedua, data nomor urut 4 hasil observasi.

d. Interpretasikan dengan model interpretasi surface structure maupun deep structure. Interpretasi surface structure adalah interpretasi teks ( termasuk tuturan dan prilaku) dan fakta. Dalam penelitian ini pemaknaan terlebih dahulu difokuskan pada persoalan yang tertuang dalam teks 
atau terungkap ketika dilakukan wawancara atau realitas yang muncul. Dari interpretasi ini, kemudian dikembangkan dengan interpretasi deep structure untuk mengungkap makna-makna yang tersirat dibalik penuturan informan, maupun aktifitasaktifatas yang mereka lakukan.

e. Komparasi integratif antar informasi pada masing-masing permasalahan dan antar sumber informasi yang diperoleh dari informan.

\section{HASIL PENELITIAN DAN PEMBAHASAN}

\section{Hasil Penelitian}

Berdasarkan hasil pre test terhadap para peserta Diklat Multikultural di Balai Diklat Keagamaan Semarang Angkata | tahun 2016 dan perbincangan antara penulis dengan peserta diklat sebelum memulai pembelajaran, menunjukkan adanya kerancuan pemahaman antara agama dan budaya. Salah seorang peserta diklat berinisial $\mathrm{AKH}$ yang bercelana cingkrang dan berjenggot panjang menyatakan: "saya memanjangkan jenggot karena saya berniat mengamalkan ajaran Islam. Ketika saya melaksanakan ibadah haji di Makkah, tempat lahirnya agama Islam, saya melihat orang-orang Arab semuanya memanjangkan jenggotnya, tidak ada yang mencukurnya, karena hal itu memang ajaran Islam. Demikian juga saya berpakaian seperti ini sambil menunjuk celana cingkrangnyajuga dalam rangka melaksanakan ajaran Islam" ( Ngamilah: AKH; 5 Juni 2016). Saya menilpun $\mathrm{MH}$ peserta dari Kebumen untuk menanyakan tentang dia memanjangkan jenggotnya, dia menjawabnya sebagai mengikuti sunnah nabi, bahwa nabi menjangkan jenggotnya. (Ngamilah, $\mathrm{MH} ; 7$ Juni 2016). Sementara SR peserta diklat dari Kabupaten Demak mengatakan “orang Indonesia banyak yang berpeci karena mayoritas penduduk Indonesia beragama Islam. Orang memakai peci merupakan indikator kuatnya keberagamaan mereka (Islam)" (Ngamilah, SR: 10 Juni 2016). Peserta diklat wanita berinisial FA yang berasal dari Kabupaten Banjar Negara mengatakan "Wanita memakai Jilbab adalah dalam rangka mengamalkan ajaran agamanya (Islam), karena Islam memerintahkan kepada wanita untuk menutup aurat dan seluruh tubuh wanita selain wajah dan telapak tangannya adalah aurat. Dengan nada yang sama juga dinyatakan $\mathrm{MH}$ peserta diklat (wanita) berasal dari Kabupaten Sragen. Hanya saja, ia menambahkan kalau ada orang non muslim Indonesia yang memakai peci dianggapnya sebagai budaya orang Indonesia" (Ngamilah, FA: 2 Mei 2016 ). Terkait dengan budaya berjanjenan dan dzibaan, UB salah seorang peserta diklat yang berasal dari Kota Salatiga menyatakan" pembacaan kitab Barzanji karangan Syekh Ja'far al-Barzanji merupakan bagian dari ibadah kepada Allah Subhanahu Wata'ala dan di dalamnya terdapat keutamaan yang dapat diambil. Lebih jauh ia mengatakan bahwa dengan membaca barzanji seseorang telah mengenang dan memuliakan Nabi Muhammad Shallallahu 'alaihi wa sallam, sehingga mereka akan memperoleh ketentraman, kedamaian dan keberkahan yang melimpah, dan dapat menghilangkan kesialan dalam keluarga. (Ngamilah: UB: 5 Mei 2016). la juga berkeyakinan bahwa dengan mengamalkan manakib secara 
teratur merupakan salah satu kiat rohaniah untuk memperlancar rezeki. Lebih jauh_ia mengatakan apabila ada orang tidak mampu menunaikan ibadah haji lantaran tidak ada biaya, amalkan Jawahirul Maani secara teratur. Insya Allah, rezeki akan mengalir dan keinginan melaksanakan ibadah haji tercapai. Saya sudah menunaikan haji lima kali karena rajin membaca manakib, tandasnya" (Ngamilah, UB: 5 Mei 2016).

\section{Pembahasan}

Mengawali pembahasan hasil penelitian ini, penulis akan menguraikan beberapa hal yang akan dijadikan pijakan dalam menganalisa data penelitian yang penulis dapatkan di lapangan. Beberapa hal tersebut adalah tentang apa itu agama, budaya dan apa keterkaitan antara Agama dan Budaya.

\section{Apa itu Agama ?}

Kata agama berasal dari bahasa Sansekerta dari kata a berarti tidak dan gama berarti kacau. Kedua kata itu jika dihubungkan sehingga menjadi kata "agama" berarti sesuatu yang tidak kacau. Jadi fungsi agama dalam pengertian ini memelihara integritas dari seorang atau sekelompok orang agar hubungannya dengan Tuhan, sesamanya, dan alam sekitarnya tidak kacau. Dari pengertian ini jugalah yang terdapat dalam kata religion (bahasa Inggris) yang berasal dari kata religio (bahasa Latin), yang berakar pada kata religare yang berarti mengikat. Dalam pengertian religio termuat peraturan tentang kebaktian bagaimana manusia mengutuhkan hubungannya dengan realitas tertinggi (vertikal) dalam penyembahan dan hubungannya secara horizontal (Sumardi, 1985:71) Kemudia
Islam juga mengadopsi kata agama, sebagai terjemahan dari kata Al-Din seperti yang dimaksudkan dalam QS Ali Imran [3]: 19 (Zainul Arifin Abbas, 1984 : 4). Agama Islam disebut Din dan Al-Din, sebagai lembaga llahi untuk memimpin manusia untuk mendapatkan keselamatan dunia dan akhirat. Secara fenomenologis, agama Islam dapat dipandang sebagai Corpus syari'at yang diwajibkan oleh Tuhan yang harus dipatuhinya, karena melalui syari'at ita hubungan manusia dengan Allah menjadi utuh. Cara pandang ini membuat agama berkonotasi kata benda sebab agama dipandang sebagai himpunan doktrin. Sijabat merumuskan pengertian agama sebagai suatu keprihatinan maha luhur dari manusia yang terungkap selaku jawabannya terhadap panggilan dari yang Maha Kuasa dan Maha Kekal. Keprihatinan yang maha luhur itu diungkapkan dalam hidup manusia, pribadi atau kelompok terhadap Tuhan, terhadap manusia dan terhadap alam semesta raya serta isinya" (Sumardi, 1985:75).

\section{Apa itu Budaya?}

Menurut Koentjaraningrat (1987:180)

Budaya adalah keseluruhan sistem, gagasan, tindakan dan hasil kerja manusia dalam rangka kehidupan masyarakat yang dijadikan milik manusia dengan belajar. Jadi budaya diperoleh melalui belajar. Tindakan-tindakan yang dipelajari antara lain cara makan, minum, berpakaian, berbicara, bertani, bertukang, berrelasi dalam masyarakat adalah budaya. Tapi kebudayaan tidak saja terdapat dalam soal teknis tapi dalam gagasan yang terdapat dalam fikiran yang kemudian terwujud dalam seni, tatanan masyarakat, ethos kerja dan pandangan hidup. Yojachem 
Wach berkata tentang pengaruh agama terhadap budaya manusia yang immaterial bahwa mitologis hubungan kolektif tergantung pada pemikiran terhadap Tuhan. Interaksi sosial dan keagamaan berpola kepada bagaimana mereka memikirkan Tuhan, menghayati dan membayangkan Tuhan (Wach, 1998:187). Dari sini dapat disimpulkan bahwa budaya yang digerakkan agama timbul dari proses interaksi manusia dengan kitab yang diyakini sebagai hasil daya kreatif pemeluk suatu agama tapi dikondisikan oleh konteks hidup pelakunya, yaitu faktor geografis, budaya dan beberapa kondisi yang objektif.

\section{Relasi antara Agama dan Budaya}

Sebagian orang menilai bahwa antara agama dan budaya adalah merupakan dua hal yang berbeda dan tidak bisa saling dikaitkan. Budaya akan selalu. berkembang serta berubah mengikuti perkembangan beberapa unsur yang baru yang masuk dan memberikan warna pada budaya itu sendiri. Perubahan yang terjadi beserta hasil yang didapatkan dari perubahan tersebut sering kali dianggap benar oleh masyarakat, Selama perubahan tersebut membawa dampak yang positif, masyarakat tidak akan menolaknya. Dengan demikian budaya selalu terkait dengan garis horizontal, hubungan sesama umat manusia dan hubungan antara manusia dengan alam.

Sedang agama, sejak agama itu labir, biasanya selalu mengalami konsistensi dalam unsur yang ada di dalamnya. Segala aturan dan ketentuan dalam agama, sifatnya selalu tetap dan tidak dipengaruhi oleh perkembangan zaman. Agama mengajarkan kepatuhan kepada setiap penganutnya agar selalu taat kepada ajaran dari Tuhan yang disebutkan dalam kitab suci maupun dalam sabda Nabi dan Rasulnya.

Dengan demikian agama selalu terkait dengan garis vertikal, hubungan antara manusia dengan Tuhannya (http://www.bimbie.com/agama-danbudaya.htm)

\section{Keterkaitan antara Ibadah dan Muamalah}

Secara garis besar, agama Islam terdiri dari akidah, ubudiyah dan akhlak. Akidah mencakup pokok-pokok keimanan, yang intisarinya adalah mentauhidkan terhadap Allah Subhanahu Wata'ala. Ubudiyah merupakan sistem normatif ilahiyah yang mengatur hubungan antara manusia dengan Tuhannya, mengatur hubungan sesama manusia_serta mengatur hubungan antara manusia dengan alam semesta. Ubudiyah dibedakan menjadi dua, yaitu yang mengatur tatacara ibadah mahdhah dan tatacara mu'amalah yaitu hubungan antara manusia dan alam. Adapun akhlak merupakan pengetahuan atau ajaran tentang baik-buruk berkaitan dengan perangai, karakter, jiwa dan perilaku manusia kepada Tuhannya, sesama manusia, dan alam. Akidah, ibadah, muamalah, dan akhlak merupakan satu sistem yang antara satu dengan yang saling terkait, tidak dapat dipisahpisahkan, melainkan saling berkorelatisi.

Yang rentan menimbulkan masalah dalam tiga hal tersebut adalah yang berkaitan dengan ibadah mahdhah dan muamalah. Tentang ibadah, terdapat rambu-rambu yang berupa kaidah ushulfikih yang menyatakan: 
لأصل في العبادة الحظر , فلا يشرع منها إلا ما شرعه الله و رسوله

"Ibadah itu pada dasarnya dilarang kecuali yang diperintahkan oleh Allah dan Rasul-Nya". ( al-Usaimin, 1416 H: 72 )

Allah SWT sudah menetapkan pokokpokoknya, sedangkan Rasulullah SAW menjelaskan tata-caranya. Dalam ibadah dasarnya adalah mengikuti perintah dan contoh dari Nabi saw. Oleh karenanya dalam hal ibadah tidak ada ruang untuk "kreativitas'dalam melaksanakannya. Perbedaan masih dimungkinkan terjadi dalam furu'nya atau hal-hal yang tidak pokok. Hal ini terjadi karena terjadinya multi tafsir terhadap dalil-dalil naqlinya disamping persoalan yang menyangkut kuat-lemahnya sebuah hadis. Sepanjang berlandaskan dalil-dalil —naqli, perbedaan dapat ditolerir.

Terkait dengan ibadah mahdhah yang sering menjadi perdebatan adalah dalam pelaksanaannya. Misalnya, bacaan doa qunut dalam shalat shubuh, shalat tarawih antara delapan rekaat dan dua puluh rekaat, adzan satu kali atau dua kali dalan pelaksanaan ibadah jumat, membaca basmalah dan shalawat oleh muadzin sebelum mengumandangkan adzan, melafalkan niat shalat sebelum takbiratul ihram dalam shalat, dan bersalam-salaman sesudah shalat berjamaah. Satu pihak berpendapat hal itu tidak diperbolehkan karena tidak ada contoh dari Nabi SAW. Pihak lain memperbolehkan karena hal itu dilakukan di luar (sebelum atau sesudah) ibadah. Persoalannya adalah karena amalan itu dilakukan secara rutin dan berurutan langsung dengan pelaksanaan ibadah, maka bisa menimbulkan kesan atau pemahaman bahwa amalan itu bersifat wajib dan merupakan bagian dari syarat atau rukun ibadah. Pemahaman yang demikian yang harus diluruskan.

Jika yang terkait dengan ibadah dasar utamanya adalah mengikuti perintah dan contoh dari Nabi, maka yang terkait dengan muamalah dasar utamanya adalah ketentuan syariah yang didapatkan dari pemahaman terhadap hakekat, tujuan, alasan, dan masiahat di balik ketentuan tersebut. Dengan kata lain, dalam hal muamalah ketentuan syariah tidak seketat seperti dalam ibadah, dalam arti masih ada ruang untuk mempertimbangkan berbagai variabel dan ruang untuk kreativitas sebagaiman dinyatakan dalam Qaidah ushul fiqih "al-hukmu yaduru ma'al 'illati wujudan wa 'adaman" (hukum itu bisa berubah menjadi ada dan tidak ada berdasarkan alasan-alasannya).

Dalam hal ibadah mengacu pada kaidah "semua dilarang kecuali yang diperintahkan", sementara dalam hal muamalah, termasuk adat, tradisi, dan produk-produk budaya, mengacu pada qaidah "semua boleh kecuali yang dilarang" (al-ashlu fil 'adati al-ibahah illa ma warada tahrimuhu).Hal ini dimaksudkan agar dalam hal muamalah menusi dibiarkan untuk berkreasi seluasluasnya. Kreativitas atau kepeloporan untuk menciptaan kebaikan- kebaikan justru didorong, sebagaimana sabda Nabi SAW :

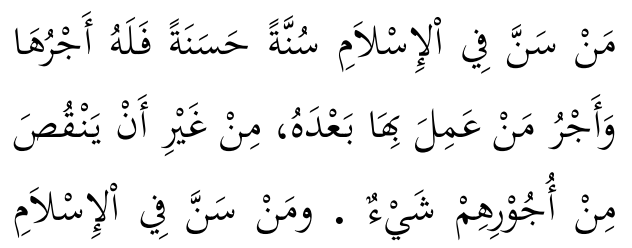




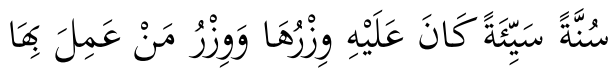

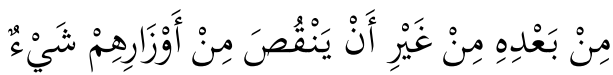

"Siapa yang melakukan satu sunnah hasanah (sunnah yang baik) dalam Islam, maka ia mendapatkan pahalanya dan pahala orang- orang yang mengamalkan sunnah tersebut setelahnya tanpa mengurangi pahala-pahala mereka sedikitpun. Dan siapa yang melakukan satu sunnah sayyiah (sunnah yang jelek) dalam Islam, maka ia mendapatkan dosanya dan dosa orang-orang yang mengamalkan sunnah tersebut setelahnya tanpa mengurangi dosa- dosa mereka sedikitpun." (HR. Muslim)

\section{Antara Sunnah dan Bid'ah}

As-Sunnah adalah segala sesuatu yang bersumber dari Nabi baik dalam bentuk ucapan (qauliyah, perbuatan (fi'liyah) atau sikap (taqririyah). Yang dimaksudkan adalah sebagai tasyri (pensyariatan) yang harus diikuti dan diteladani oleh ummat Islam. Pensyariatan merupakan penetapan sesuatu sebagai bagian dari syariat agama. Tersirat dalam pemahaman ini bahwa tidak semua ucapan, perbuatan, dan penetapan dari Nabi disebut as-Sunnah. Yang menjadi persoalan adalah bagaimana memastikan bahwa ucapan, perbuatan, dan ssikap Nabi itu dimaksudkan atau tidak dimaksudkan sebagai pensyariatan.

Definisi yang lain menyebutkan bahwa lingkup dari As-Sunnah adalah menyangkut persoalan- persoalan keagamaan, yaitu menyangkut akidah dan ibadah, di luar itu tidak termasuk sunnah. Ucapan dan perbuatan Nabi Saw berkaitan dengan rincian Rukun Iman dan Rukun
Islam adalah As-Sunnah yang harus diikuti. Tapi ucapan dan perbuatan Nabi SAW di luar itu tidak termasuk dalam As-Sunnah. Rumusan ini memaknai agama secara sempit, karena hanya menyangkut akidah dan ibadah saja. Sementara agama Jslam mencakup berbagai aspek kehidupan. Tapi pendapat sebaliknya yang memasukkan semua hal dari Nabi SAW (termasuk cara berjalan, cara makan, bentuk pakaian, dan sejenisnya) ke dalam pengertian AsSunnah juga berlebihan.

Adapun Bid'ah secara harfiah berarti "ciptaan baru". Bid'ah masuk ke dalam terminologi agama berdasarkan hadis Nabi SAW yang diriwayatkan oleh Abu Dawud dari Iryadh ibn Sariyah. Dia berkata, "Rasulullah SAW pada suatu ketika memberikan nasihat yang sangat bijak, membuat hati kami bergetar dan mencucurkan air mata. Seorang dari kami berkata, "nasehat itu seakan-akan merupakan nasehat perpisahan ya Rasul, maka berikanlah kepada kami nasehat lagi". Nabi SAW bersabda: "Aku wasiatkan kepada kalian agar bertakwa kepada Allah, mau mendengarkan dan menaati (nasehat yang baik) meskipun dari seorang budak habasyi. Barangsiapa mengalami hidup sesudahku, akan menyaksikan banyak perselisihan, maka hendaklah kalian berpegang teguh kepada sunnahku dan sunnah Khulafa'ur Rasyidin, pegangilah erat-erat, gigitlah dengan gigi geraham kalian. Hindarkan diri kalian dari perkaraperkara baru, karena setiap yang baru itu bid'ah, setiap bid'ah itu sesat. Hadis lain riwayat An-Nasa'i dari Jabir ibn Abdullah dengan redaksi yang sama tapi dengan tambahan "dan setiap kesesatan itu masuk neraka". Kemudian hadis yang bersumber dari 'Aisyah diriwayatkan oleh Imam 
Muslim menjelaskan batasan frasa 'perkara-perkara baru', Nabi SAW bersabda: "Barang siapa melakukan amalan yang tidak ada perintah dari kami maka amalan itu ditolak". Dari hadis ini dipahami bahwa yang dimaksud dengan "perkara baru" adalah dibidang agama.

Dengan demikian, secara harfiah bid'ah adalah "ciptaan baru dalam urusan agama". Pengertian "urusan agama" yang paling dekat dengan pikiran adalah masalah akidah dan ibadah. Jadi bid'ah adalah hal berkaitan dengan akidah yang tidak diajarkan dan amal ibadah yang tidak disyariatkan oleh Allah dan Rasul-Nya. Adapun bila ada anjurannya, baik berbentuk wajib atau sunnah dengan didukung dalil-dalil syar'i terhadap anjuran tersebut, maka hal itu bagian dari agama meskipun terdapat perselisihan diantara alim ulama dalam sebagian masalah. Definisi lain mengatakan "bid'ah adalah suatu cara yang diada-adakan dalam agama, yang bentuknya menyerupai syari'at, tujuannya adalah untuk berlebihlebihan dalam beribadah kepada Allah SWT".

Dari hadis-hadis tersebut dapat disimpulkan bahwa sesuatu. disebut bid'ah apabila memenuhi tiga unsur: (1) Kebaruan atau pembaruan. Ini mencakup semua kreasi atau ciptaan baru yang belum ada sebelumnya, bisa baik atau buruk, terpuji atau tercela, dan bisa mencakup semua hal baik urusan agama maupun urusan dunia. Oleh karena itu ada unsur kedua yakni (2) Sesuatu yang baru itu dinisbatkan kepada atau dianggap sebagai bagian dari syariat agama. Batasan ini berdasarkan hadis dari 'Aisyah yang menyebut "fi amrina" (dalam urusan kami, maksudnya urusan agama). Dengan demikian, kreasi baru dalam bidang kebudayaan dalam arti luas tidak disebut bid'ah. Unsur berikutnya, (3) Sesuatu yang baru itu tidak punya landasan atau rujukan dari syariah yang sahih. Sebagai contoh, soal qunut subuh, soal shalat tarawih berjamaah dan jumlah rekaatnya 8 atau 20, tidak termasuk katagori bid'ah, karena masing-masing ada landasan syari'ahnya, meskipun terdapat perbedaan pendapat di kalangan ulama dalam beberapa segi dari permasalahan tersebut.

\section{Kerancuan antara Ajaran agama dan Budaya}

Berdasarkan hasil pre test terhadap para peserta Diklat Multikulltural di Balai Diklat Keagamaan Semarang Angkata | tahun 2016 dan wawancara serta pengamatan penulis terhadap peserta diklat, menunjukkan adanya kerancuan pemahaman antara agama dan budaya.

Banyak di antara mereka memberikan penilaian terhadap orang yang bersikap atau melakukan sesuatu, bahwa orang tersebut sedang manjalankan ajaran agamanya padahal ia mencontoh orang yang berbudaya. Sehingga ia memberikan penilaian kepada orang yang tidak melakukannya ia dianggap tidak melaksanakan ajaran agama. Beberapa kasus kiranya dapat kita ajukan sebagai contoh yang mereka komentari. Budaya pemakaian jubah yang merupakan budaya orang Arab yang sebagian orang menganggapnya hal itu sebagai ajaran Islam, karena Nabi selalu mengenakan pakaian itu. Pada hal orang kafir juga berpakaian jubah karena memang budaya berpakaian orang Arab seperti itu. Yang termasuk ajaran agama adalah menutup aurat, sedang model pakaian yang digunakan untuk menutup aurat, agama 
tidak menentukan, melainkan memberi kebebasan umatnya untuk berkreasi. Jadi menutup aurat dengan model pakaian apapun tetap dihitung sudah termasuk melaksanakan ajaran agama dalam hal menutup aurat, tidak harus dengan pakaian jubah. Bagi kaum wanita oleh ajaran agama (Islam ) diperintahkan untuk menutup aurat. Aurat wanita adalah selurah badannya kecuali muka dan kedua telapak tangannya.(Yahya bin Syarif, 1427 H: 122).

Menutup kepala bagi wanita adalah bagian dari menutup aurat yang diperintahkan oleh ajaran agama. Namun agama (Islam) tidak menentukan model yang bagaimana yang digunakan untuk menutup aurat wanita bagian kepala. Tentang model agama memberi kebebasan untuk berkreasi, bisa berupa jilbab dan juga bisa dengan model yang lain.

Terkait soal pakaian jilbab dan kerudung ini, bagi kalangan Islam yang berpandangan bahwa pakaian adalah soal tradisi budaya semata, maka jilbab akan dipersepsikan sebagai bagian dari budaya orang Arab atau budaya orang Timur Tengah. Artinya, tidak ada keharusan untuk mengenakan jilbab dan kerudung tersebut. Sebab, budaya lokal Indonesia mempunyai tatacara berpakaian sendiri yang dianggap cocok, yang berbeda atau belum tentu sama dari daerah lain. Tegasnya bagi mereka, jilbab dan kerudung tidak lebih dari produk budaya yang tahir di Arab. Sebaliknya, untuk umat Islam yang meyakini bahwa masalah pakaian merupakan salah satu cabangsyariat Islam, otomatis akan menganggap menggunakan jilbab dan kerudung adalah salah satu kewajiban agama sekaligus identitas keislaman seseorang muslimah.
Di Indonesia pemakaian peci bagi kaum laki-laki dalam anggapan banyak orang merupakan simbul orang muslim. Sehingga kalau ada orang memakai peci maka sebagai pertanda bahwa orang tersebut adalah muslim. Sementara banyak didapati orang yang memakai peci namun ia bukan seorang muslim. Dan sebaliknya banyak orang beragama Islam meskipun mereka tidak memakai peci. Peci adalah budaya orang Indonesia, bukan simbul muslim.

Demikian pula budaya memanjangkan jenggot yang nabi biasa melakukannya. Karena ini merupakan budaya Arab, maka orang Arab ya banyak yang melakukannya, meskipun bukan pengikut Rasulullah. Orang non Arab ada yang menganggap memanjangkan jenggot sebagai sebuah ajaran, sehingga mereka memberikan penilaian bahwa orang yang tidak memanjangkan jenggot dianggap tidak melakukan sunnah Nabi. Substansi ajaran yang dapat diambi! adalah aspek kepantasan. Bagi yang memiliki jenggot yang lebat, dipanjangkan akan menambah kepantasan, ketampanan dan kegagahan. Akan tetapi bagi yang jenggotnya tidak lebat, hanya beberapa helai saja yang tumbuh, barangkali kalau diperpanjang justru akan kelihatan aneh, maka kalau sekiranya dipanjangkan tidak memenuhi unsur kepantasan, maka membersihkannya justru lebih baik.

Terkait pembacaan kitab al-Barzanji dan Manakiq di Indonesia sebenarnya merupakan bagian dari seni budaya yang berkembang di kalangan pesantren dan masyarakat.Kitab al- Barzanji yang ditulis Syekh Abu Ja'far bin Hasan bin Abdul Karim al-Barzanji merupakan kitab yang berisi seajarah kehidupan Nabi Muhammad saw 
muali dari fahir sampai meninggal. Sementara kitab Manaqib yang juga ditulis oleh Syaikh Ja'far bin Hasan bin Abdul Karim Al-Barzanji merupakan kitab yang berisi biografi seorang waliyullah Syekh Abdul Qodir al- Jiilani. Membaca kitab yang berisi biografi Nabi Muhammad dan Syekh Abdul Qadir al-Jiilani sebenarnya ya membaca buku biasa sebagaimana membaca buku-buku lainnya yang berisi tentang sejarah tentang sejarah Nabi. Hanya saja kedua kitab ini ditulis dalam bahasa sastera dan cara membacanya juga dilagukan. Perihal membaca dengan lagu dan suara yang merdu merupakan seni budaya. Namun masyarakat mengsakralkannya sehingga hal ini dianggap merupakan ibadah dan bagian dari ajaran agama, sehingga dalam konteks ini sulit dipisahkan antara budaya dan pengamalan ajaran agama.

\section{Mengposisikan Ajaran Agama dan Budaya}

Agama merupakan sebuah tatanan dan ajaran yang bersifat vertikal yang menjabarkan hubungan antara manusia dengan Tuhannya. Sedangkan budaya lebih dominan pada tatran horizontal, hubungan antara sesama manusia dan hubungan antara manusia dengan alam. Dari aspek penciptaannyapun antara agama dan budaya menempati posisi yang berbeda. Agama merupakan sebuah pemahaman yang bersumber dari Tuhan dan diciptakan untuk dipatuhi manusia. Posisi manusia dalam agama adalah sebagai pelaksana atas segala ketentuan yang sudah ada. Semua aturan dan ketentuan yang ada dalam agama sudah ditentukan oleh Tuhan, manusia tidak memiliki kekuatan untuk melakukan perubahan, terutama yang menyangkut pokok pokok ajaran suatu agama seperti doktrin keimanan dan ibadah mahdlah.

Sementara budaya lahir dan tercipta karena peran manusia. Budaya lahir karena adanya manusia yang berpikir, berkreasi, berkarsa dengan menggunakan akalnya. Budaya diciptakan manusia guna memperbaiki, membantu. manusia serta sebagai upaya peningkatan kualitas hidup manusia dan lingkungannya. Budaya merupakan akumulasi dari proses berpikir manusia yang ditujukan untuk menciptakan pemahaman serta berinteraksi dengan lingkungannya.

\section{Idealisme Penyelenggaraan Diklat Multikultural}

Kedepan, sistem pendidikan agama dan keagamaan perlu melakukan perubahan yang mendasar dengan mengembangkan paradigma keragaman yang demokratis, berkeadilan dan tidak diskriminatif. Hal ini merupakan langkah strategis untuk membangun kembali masyarakat dan bangsa Indonesia yang lebih bermartabat dan berkeadaban. Pendidikan agama dan keagamaan sebagai bagian dari sistem pendidikan nasional sudah semestinya dapat memberikan kontribusi dalam menanamkan nilai-nilai keragaman, saling memahami dan menerima perbedaan sesama warga yang berbeda etnik, sosial, budaya dan agama yang bersumber dari ajaran agama. Pendidikan agama diharapkan dapat memberikan tawaran alternatif bagi berkembangnya etika sosial yang lebih humanistik dan multikultural bersumber dari ajaran agama.

Pendidikan multicultural masih sulit dilaksanakan bahkan masih perlu dirumuskan aspek-aspeknya. Pertama, apa yang disebut multikulturalisme itu, apa 
saja materinya keragaman agama, atau keragaman budaya, apakah bersifat kognitif, atau bersifat pendekatan pembelajaran, berapa porsinya, dan sebagainya. Kedua, bagaimana metode guru agama dalam mengajarkannya, guru yang bagaimana yang mampu mengajarkannya, diklat apa yang diperlukan oleh para guru agama itu, dan sebagainya. Ketiga, sarana apa saja yang dapat mendukung wawasan multikulturalisme itu, buku sumber belajar yang bagaimana, alat belajar mengajar apa dan bagaimana yang diperlukan dan sebagainya. Keempat, lingkungan sosial yang bagaimana yang diperlukan itu.

Indonesia merupakan bangsa yang memiliki keragaman dan kebinekaan dalam banyak aspek. Keragaman dan kebinekaan dalam satu sisi merupakan kekayaan yang tidak ternilai. Namun pada satu sisi keragaman dan kebinekaan merupakan sumber potensi timbulnya konflik yang bisa mengancam keutuhan bangsa, Oleh karenanya keragaman dan kebinekaan harus ada pengelolaan yang baik. Salah satu bentuknya adalah memberikan bekal tetntang wawasan multikultural kepada berbagai elemen bangsa. Dalam hal ini Guru dan Dosen patut untuk dipertimbangkan untuk diberi pembekalan wawasan multikultural dalam bentuk kediklatan, dengan harapan agar mereka nantinya menjadi agen perubahan menuju harmonisasi bangsa. Karena Identitas kolektif keagamaan siswa, berpengaruh secara tidak langsung pada sikap multikulturalisme lewat persepsi multikulturalisme siswa. Temuan ini menegaskan pentingnya menanamkan persepsi teologis yang tepat untuk mengembangkan sikap dan identitas kolektif positif. Demikian pula halnya dalam pembentukan sikap multikulturalisme, persepsi teologis dan multikulutralisme sangat penting dalan rangka mengembangkan sikap multikulturalisme dalam diri siswa. Persepsi teologis yang mendalam tapi tidak tepat diasumsikan dapat menyebabkan sikap teologis kurang sehat yang akan berimplikasi kurang baik terhadap pembentukan identitas kolektif keagamaan dan pembentukan persepsi multikulturalisme siswa.

Justru materi wawasan multikultural harus diberikan pada semua program kediklatan yang diselenggarakan oleh Badan Litbang dan Diklat Kementerian Agama maupun yang diselenggarakan oleh lembaga-lembaga lain.

\section{PENUTUP}

\section{Kesimpulan}

Berdasarkan uraian dan membahasan di atas dapat disimpulkan sebagai berikut :

a. Agama adalah sebagai suatu keprihatinan maha luhur dari manusia yang terungkap selaku jawabannya terhadap panggilan dari yang Maha Kuasa dan Maha Kekal. Keprihatinan yang maha luhur itu diungkapkan dalam hidup manusia, pribadi atau kelompok terhadap Tuhan, terhadap manusia dan terhadap alam semesta raya serta isinya"

b. Antara agama dan budaya sekalipun memiliki kedekatan hubungan yang erat, namun sebenarnya dapat dibedakan, dipisah dan didudukkan dalam posisinya masing masing. Agama sejak kelahiranya, selalu 
mengalami konsistensi dalam unsur yang ada di dalamnya. Segala aturan dan ketentuan dalam agama, sifatnya selalu tetap dan tidak dipengaruhi oleh perkembangan zaman. Agama mengajarkan kepatuhan kepada setiap penganutnya agar selau taat kepada ajaran dari Tuhan yang disebutkan dalam kitab suci maupun dalam sabda Nabi dan _ Rasulnya. Sedang budaya akan selalu berkembang serta berubah mengikuti perkembangan beberapa unsur yang baru yang masuk dan memberikan warna pada budaya itu sendiri. Perubahan yang terjadi beserta hasil yang didpatkan dari perubahan tersebut sering kali dianggap benar oleh masyarakat.

c. Agama dapat diposisikan sebagai tatanan dan ajaran yang bersifat vertikal yang menjabarkan hubungan antara manusia dengan Tuhannya. Sedangkan budaya lebih dominan pada tatran horizontal, hubungan antara sesama manusia dan hubungan antara manusia dengan alam. d. Kerancuan pemahaman terhadap agama dan budaya terjadi pada berbagai aspekkehidupan terkait dengan perilaku, etikan berbusana dan aspek-aspek kehidupan lainnya yang asalnya merupakan budaya yang dimiliki oleh bangsa atau kelompok masyarakat fertentu

\section{Rekomendasi}

Berangkat dari temuan-temuan penelitian sebagaimana yang telah dipaparkan di atas, maka direkomendasikan hal-hal sebagai berikut:

a. Untuk menghindari kekaburan antara ajaran-ajaran agama dan budaya, perlu adanya penguatan dan penekanan antara batas-batas pelaksanaan ajaran agama dan berbudaya.

b. Dalam pelaksanaan diklat multikultural, hendaknya ada penguatan wawasan pembedaan antara pelaksanaan ajaran agama dan berbudaya.

\section{DAFTAR PUSTAKA}

Azyumardi Azra. 1995. Jaringan Ulama Timur Tengah dan Kepulauan Nusantara abad XVII dan XVIII. Bandung. Mizan, cetakan 3

Al Utsaimin, Muhammad Bin Shalih, 1416 H, Al Shahwah Al Islamiyah, Dhawabit Wa Taujihaat, Riyadh: Daar Al Qaasim Li An Nasyr, Cet.III

Emile Durkheim. 1992. Sejarah Agama (terj. The Elementary Forms of the Religious Life) Yogyakarta: IRCiSoD

Hafidz Shaleh. 2003. Metode dakwah Al-Quran (terj. Nahju al-Quran fi Ad-Dakwah) Bogor: Al Azhar Press

2003. Falsafah Kebangkitan Dari Ide Hingga Metode. (terj. AnNahdhah). Bogor: Idea Pustaka Utama 
http://www.eramuslim.com/suara-kita/pemuda-mahasiswa/suchail-suyutimahasiswa-pascasarjanan-ui-budaya-indonesia-dan-syariatislam.htm\#.V4INT270vIV

Koetjaraningrat. 1985. Kebudayaan, Mentalitas dan Pembangunan. Jakarta. Gramedia Muhammad Husain Abdullah. 1994. Mafahim Islamiyah. Beirut: Darul Bayariq 1990. Dirasat fi al-Fkri al-Islamiy. Beirut: Darl Bayariq

Muhammad Muhammad Ismail. 1993. Bunga Rampai Pemikiran Islam (terj. Al-Fikru AlIslamy). Jakarta: Gema Insani Press.

Parsudi Suparlan. 2003. Hubungan Antar Suku bangsa. Jakarta. Yayasan Ilmu Kepolisian

Pendekatan Budaya terhadap Agama, Ditjen Pembinaan Kelembagaan Agama Islam Departemen Agama, R.I. Tugu, Bogor, 1994

Patilima, Hamid. 2010. Metode Penelitian Kualitatif. Malang: UMM Press

Syaikh Sami Ash Shuqair, 2013, Syarah Manzhumah Ushul Fiqh wa Qawa'iduh, Cet. 3

Syaikh Muhammad bin Husain Al Jizani, 2013, Dirasah wat Tahqiq Qaidah Al Ashl fil Ibadah Al Man'u,

Syamsuddin Ramadhan al-Nawi. 2007. Hukum Islam Seputar Busana dan Penampilan Wanita. Yogyakarta: Ar Raudhoh Pustaka. Lihat juga Taqiyuddin an-Nabhany. 1990. An-Nidham al-ljtimaiy fi al-Islam. Beirut.: Darul Ummah Cet.3

Taqiyuddin An-Nabhany. 2001. Nidhamu Al-Islam. Ttp. Hizbut Tahrir. Edisi 6 (edisi muktamadah)

Yudi Ruyadi, MODEL PENDIDIKAN KARAKTER BERBASIS KEARIFAN BUDAYA LOKAL(Penelitian terhadap Masyarakat Adat Kampung Benda Kerep Cirebon Provinsi Jawa Barat untuk Pengembangan Pendidikan Karakter di Sekolah) dalam ; Proceedings of The International Conference on Teacher Education; Join Conference UPI \& UPSI Bandung, Indonesia, 8-10 November 2010

Yahya bin Syarf An Nawawi, 1427 H, Al Majmu' Syarh Al Muhaddzab lisy Syairozi, terbitan Dar 'Alamil Kutub, cetakan kedua.

Vita Fitria, Interpretasi Clifoort geetz tentang Budaya : Agama sebagai System Budaya, dalam : SOSIOLOGI REFLEKTIF, Volume 7, Nomor 1, Oktober 2012 